\title{
Maternal Work and Child-Care Strategies in Peri-Urban Guatemala: Nutritional Effects
}

\author{
Patrice L. Engle \\ California Polytechnic State University, San Luis Obispo
}

\begin{abstract}
Associations of 293 mothers' work for earnings and child-care arrangements with the anthropometric status of their children were examined in urban Guatemala. It was hypothesized that during the period of life in which growth often falters ( 8 through 35 months), maternal employment could be beneficial for children. Informal workers tended to be poorer, less educated, and have more undernourished children than formal workers or nonworkers. When poverty and mother's education were controlled for, no effects of maternal employment on children's anthropometric growth patterns were seen. However, the percent of the family income the mother earned was positively associated with all anthropometric indicators, controlling for confounds. Children taken care of by preteen siblings had significantly lower weight for height than those in other situations, even controlling for SES and maternal employment status. These effects were not found in a 36-48-month-old sample.
\end{abstract}

In the last decade, many investigators have become concerned about the consequences of changing patterns of maternal employment for children's healthy development. In the United States, this concern has led to studies of psychosocial development, attachment, and school achievement. In the more difficult circumstances in developing countries, the consequences of maternal employment are being measured in terms of the health, growth, and survival of children (e.g., Engle, 1983; Leslie, 1988; Leslie \& Paolisso, 1989; O’Gara, 1989; Tripp, 1981; Tucker, 1989).

Maternal work for earnings in developing countries is not a new phenomenon, but some of its forms (e.g., leaving the home for extended periods to work in places where one cannot take the child) are different. As the culture urbanizes and maternal work for earnings becomes more common, new systems for child rearing are developed. In order to understand the effects of maternal employment for children, one must consider adaptations such as choice of caregiver, the caregiving setting, how the mother's income changes the family spending patterns, or beliefs about alternative child care. For example, a number of recent studies have suggested that poor mothers tend to use a higher percent of their income for meeting the basic needs of children than will fathers (Blumberg, 1988; Dwyer \& Bruce, 1988; Engle, 1990). Child-care beliefs are often discrepant with reality; Engle (1989b) reported, in Guatemala, that for $70 \%$ of women, the ideal child caretaker was the child's grandmother, but only $14 \%$ of children were actually watched by their grandmothers.

Leslie's $(1988,1989)$ recent review of 25 studies from 16 developing countries found no conclusive evidence linking maternal employment with poorer nutritional status of children. The studies that did find effects of maternal work on children did not control for other potentially confounding variables, such as poverty, limiting the possibility of making causal statements. Part of the reason for the lack of consistent findings in this area has been the simplicity of the theoretical mechanisms proposed. Studies have generally considered maternal work as a dichotomous variable, and have not measured the hours the woman works, the quality of the alternative caregiver, her type of work, or developmental changes in children's needs (Leslie, 1989). Some studies have shown that the effects of maternal work for earnings depended on the type of work (Engle \& Pedersen, 1989; Wolfe \& Behrman, 1982) and

An earlier form of this paper was presented at the Society for Research in Child Development meetings, April 28, 1989. Support for this work came from a Fulbright Research Scholarship and a State Faculty Support Grant. The assistance of Henry Hammer in data preparation and Marta Amanada Barrera in interviewer training is most appreciated. Correspondence concerning this article should be addressed to the author at the Department of Psychology and Human Development, Cal Poly, San Luis Obispo, CA 93407. 
amount of time working (Soekirman, 1985). Type of work is probably a proxy for income or wage rates, and working for a higher wage rate would increase possible benefits for children. Amount of work is probably an indicator of maternal time with the child, and therefore should be a better indicator for predicting consequences for children than a simple dichotomous variable. Both work type and amount of time working are examined in this study.

The current trend in cross-cultural developmental psychology is to focus on the child-in-context, studying the ecological context as well as the individual child. The concept of the "developmental niche" of the child (Super \& Harkness, 1986) has been proposed as a "theoretical framework for studying cultural regulation of the microenvironment of the child" (p. 552). The environment is considered to have three component subsystems: (1) the physical and social setting in which the child is placed, (2) the culturally regulated customs of child care and child rearing, and (3) the caregivers' beliefs about development. Each of these will influence, and be influenced by, work patterns and child-care strategies.

The developmental niche of an employed mother's child also will depend on the child's age, a variable rarely considered in research on maternal employment in developing countries (Leslie, 1989). During the first 4 years of a child's life, the kinds of conditions that compromise growth and development vary tremendously. The relative importance of the mother's time in caregiving and the nutritional benefit of her extra income should also vary by the child's age. Specifically, the period of development during which maternal income might be most important for children's growth and development should be when supplementary feeding has become the major source of food, and before growth trajectories have become well established. This developmental period, approximately 8-9 months through the third year, is generally considered to be the period during which growth begins to falter compared to U.S. norms (Grant, 1989).

During the first months of life, the major determinants of nutritional status are characteristics of the mother, such as prepregnancy weight and pregnancy weight gain, and at birth the majority of children are adequately nourished (Herrera, 1987; Johnston, Newman, Cravioto, DeLicardie, \& Scholl, 1980;
Mueller \& Pollitt, 1983). However, rates for malnutrition and infection peak in the second year (13-24 months) (Gordon, Wyon, \& Ascoli, 1967), and the proportion of children dying matches or exceeds the total dying in the following 3 years (Puffer \& Serrano, 1973). Martorell and Klein (1980) found that most of the growth differentials between children that are well and poorly nourished occurred between 8 and 30 months of life.

There are several reasons for this decline in growth rate and health. Diarrhea tends to increase as the child begins to be mobile and can become infected more easily. Weaning foods are often inadequate because of low caloric density and contamination (Gibbons \& Griffiths, 1984). Other family members begin to take a larger role in child care, whether or not the mother is working (Werner, 1988). Cassidy (1980), in her cross-cultural survey of behaviors during the second and third years of the child's life, argues that "many weaning customs of nonindustrialized peoples potentiate malnutrition" (p. 109). Customs common during this period, such as restricting "strong" or protein-rich foods, allowing competition for food with older children or the preferred sex, or separating the child from the mother for a period of time, increase the likelihood of malnutrition.

In urban Guatemala, other family members begin to take a substantial role in child care after the first year (Engle, 1989a). One could predict that the extra income a mother can provide for the purchase of high-quality weaning foods during this period would facilitate growth, whereas the loss of her time might be less critical, since her caregiving is beginning to be replaced anyway. Caregiving quality should continue to be important for tasks such as protecting children from infection or feeding (Zeitlin, Houser, \& Johnson, 1989), whether performed by mother or an alternate.

Beyond the age of 36 months, the change in the growth rate of the child does not appear to be influenced substantially by dietary intake until the child reaches puberty. Relatively few differences between the growth rates of well and poorly supplemented children were found after 30 months (Martorell \& Klein, 1980). Growth curves become much more steady (Berkey \& Reed, 1987). Risk of diarrhea is less, and the child is more capable of self-care. Thus, little effect of maternal income on children's growth pattern should be found in this age cohort. 
Evidence that the quality of alternate child care when mothers are working for earnings has an effect on the child's nutritional status is surprisingly scarce (Joekes, 1989; Leslie, 1989; Werner, 1988). A few studies suggest that children cared for by an adult will have better nutritional status than children cared for by siblings (Bittencourt \& DiCicco, 1979; Engle, 1989a; Shah, Walimbe, \& Dhole, 1979; and Tucker, 1989), but the studies cited were either not methodologically adequate, or were not able to include measures of the setting (workplace or home) or characteristics of the alternate caregiver.

The measurement of children's wellbeing used in this sample is anthropometric status, which is usually correlated with cognitive development in societies with endemic malnutrition (Engle, Irwin, Klein, Yarbrough, \& Townsend, 1979; Joos, Pollitt, Mueller, \& Albright, 1983; Sigman et al., 1988; Townsend et al., 1982). The three anthropometric measures used here measure different nutritional conditions. Height for age tends to be a long-term indicator of nutritional adequacy, less influenced by shortterm changes (Pollitt, Mueller, \& Leibel, 1982). Weight for age may reflect the same long-term growth retardation as low height. It could also result from a period of shortterm undernutrition after an episode of illness or food shortage. Weight for height can be used to distinguish the two effects, since it is a measure of wasting or body disproportion (Super, Herrera, \& Mora, 1990; World Health Organization [WHO], 1983). Low weight for height is much less common in Guatemala than low height for age and low weight for age. Low weight for height often signals serious nutritional inadequacy (Martorell, Klein, \& Delgado, 1980). Both weight and height measures are predictive of longterm growth and cognitive effects in Kenya (Sigman, Neumann, Jansen, \& Bwibo, 1989), the Philippines (Popkin \& Lim-Ybanez, 1982), and Guatemala (Johnston, Low, De Baessa, \& McVean, 1987; Pollitt, Gorman, $\&$ Metallinos-Katsaras, 1989). They may not reflect micronutrient deficiences.

In the present study, the location of the alternate care, the age of the caregiver, the type and hours of the mother's work, and the developmental period of the child were factors included in an assessment of the effects of maternal work on children's nutritional status, as measured by their weight and stature. It was hypothesized that for children from 8 through 35 months, maternal work for earnings would be associated with higher anthropometric status than for nonworkers, particularly if the mother is employed in the formal sector and if the caregiving environment is positive (care by an adult or care by mother when she is working in the home). Second, the amount of time per week she worked should be less highly associated with children's growth patterns than type of work. Finally, these effects should not be seen in a group of older (36-48-month-old) children.

\section{Method}

\section{Village Description}

The study took place in two adjacent towns about $20 \mathrm{~km}$ from Guatemala City. Regular bus service every 10 min links the town with the city. The area is $97 \%$ Ladino (Spanish-speaking, not Indian), and rapid industrialization in the nearby area has resulted in some wealth for a few residents, although most are poor and earn little at the local industries. The town is typical of many areas of new urbanization, although conditions are not as desperate as in burgeoning shantytowns that spring up on the sides of hills. The towns include much diversity economically; on the same block, one can find a cane shack where a woman might support her family by making tortillas, and a stucco house with a truck parked alongside. The older part of the town is well established, with larger adobe houses around a central square, but a newer barrio has recently been built (the second village). Main roads are paved, although most houses face onto dirt roads that become muddy puddles in the rainy season. The most common house is of stucco, with a metal roof and a cement floor, although $28 \%$ of the houses have dirt floors, and some houses have walls of cane, scrap wood, and plastic. Most (87\%) have electricity, and $44 \%$ have flushable toilets. Fiftyseven percent have televisions, but only $11 \%$ own some form of motor vehicle.

\section{Subjects}

The initial sample consisted of 302 families with children between the ages of 8 months and 47 months living in these two towns. To be selected, each family had to have an "index child" within this age range. If the family had two children within this age range, the younger was selected as the index. Of this group, the sample for this study are the 239 index children who were within the 8 month to 35 month range. In addition, a comparison was made with a group of children over 36 months (57 index 
children and 51 siblings of index children between the ages of 36 and 47 months), although this group is not strictly comparable to the younger group.

Every attempt to gather a complete $20 \%$ sample of the two villages was made. Every fifth house was selected to be included in the sample from a map and an aerial photograph. If the residents did not have a child between 8 and 47 months, one of the adjacent houses was selected for inclusion in the sample, first from the right-hand side, then from the left. Once a family with a child under 4 had been identified as a potential subject, every effort was made to include that family in the sample. Often surveys will miss families of working mothers because no one may be home at the time of the visit. In 10 families, after three visits the mother could not be located ( $3 \%$ of the families contacted). Another seven families with preschool-age children declined to participate (2\% of the families contacted). Six index children were dropped, two because they were out of the age range, and four for measurements of anthropometric status that were out of the acceptable range, or because of errors.

\section{Instruments and Procedure}

Each woman was interviewed in her home regarding her working patterns, child-care patterns, family relationships, feeding practices, and knowledge of child development. Height and weight of all children in the family under 48 months of age were assessed using a Salter Scale and a horizontal infant board. The interviewers were four Guatemalan teachers familiar with the community. They received a 3-week training procedure directed by staff members of the Institute of Nutrition of Central America and Panama (INCAP) on interviewing and assessment of nutritional status. Standardized trials with children in the local day-care center indicated that the four were within acceptable levels of reliability on the anthropometric measures using a calculation of a ratio of percent agreement with the trainer and the trainee, developed by INCAP following WHO guidelines. Reliability of the interview was obtained by $(a)$ two people coding the same interview, and $(b)$ two separate interviews of the same subject. All interviews were recorded to check for reliability of questioning and coding. At least $85 \%$ concordance was required for all instruments. All forms were reviewed by the author upon completion, and errors were re- turned to the interviewers for revisits when answers were not clear or were out of range.

\section{Variables}

Mother's work.-The women's work for earnings was assessed with a series of questions designed to capture all occasional as well as regular work. Each mother was asked whether she "did anything to earn money during the past 7 days." She was also asked whether she had done any income earning in the past 12 months. With additional questions, the number of hours per day, days per week, months per year of work, and travel time to work were assessed. From this information, it was possible to calculate the total number of hours the woman worked in the previous year and categorize women into those who worked full time (equivalent to 40 hours per week per year), part time (less than full time, but more than 8 hours per week per year), and occasional (some work, but less than 52 days a year of work). The distinction between part-time and occasional work resulted in an approximately equal number of women in each group. Categories, rather than continuous measures, were used because full-time work seems qualitatively different from other kinds of work.

The woman's primary occupation was coded on a 28-item scale, developed at INCAP in Guatemala to be appropriate to women as well as men. Although many women work as domestics in the homes of the wealthy, these women are not represented in this sample, as they did not reside in the villages. Workers were grouped into two categories: informal and formal. Formal work was characterized by owning a business such as a store in the home, having a trade such as tailoring, or working in a factory or a store. Informal work tended to have flexible hours and have no defined job skills. Although these informal activities appeared to be unscheduled, social arrangements were often well defined and consistent. Common activities were washing, ironing, and cleaning; making food products and vending them door to door or at a temporary location (e.g., making frozen "snacks" for schoolchildren and selling them after school); making home crafts to sell; buying food at a central market and selling it in the village on a daily basis; providing a service (one woman gleaned tomatoes from the fields and sold them to special clients); or making and selling tortillas door to door.

Child-care methods.-Major child-care 
strategies of working women were taking the child with them to work, leaving the child at home with another person, leaving the child in another person's house, or working at home with the child. The age of the person who watched the child was assessed.

Anthropometric measures.-All height and weight measures were transformed into $z$ scores based on normative data from the National Center for Health Statistics (Jordan \& Staehling, 1986). This transformation provides age and gender standardization, with a mean of 0 and a standard deviation of 1 , and is widely used internationally (WHO, 1983).

Modifying variables.-Mother's education was the number of years of school she reported passing. Per capita family income per month was the sum of all sources of income reported (mother's income, father's income, and help from other sources per month) divided by the number of members in the nuclear family. House quality was a scale of the quality of the wall, roof, and floor. Other variables were birth order, gender, and marital status (in a union or not in a union). For working women only, the total number of hours worked during the past year, her income per month, and the percent of the family's income she earned were calculated.

\section{Plan of Analysis}

The basic analytic strategy was, first, a one-way analysis of variance on each anthropometric indicator using work type, work amount, and type of child care as independent variables, respectively, and second, an analysis of covariance on each anthropometric indicator controlling for socioeconomic and demographic variables of mother's education, house quality, income per family member, birth order and age of child, marital status, and gender of child for each independent variable. All analyses were performed with the General Linear Model procedure (SAS Institute, 1985), which is recommended in analysis-of-covariance models with unequal cell sizes. Contrasts between categories were made using Fisher's protected $t$ tests, when appropriate, and for the child-care comparison, each of the four methods of child care was compared with nonworkers, using Bonferroni's correction for multiple comparisons (Miller, 1981).

\section{Results}

Characteristics of the sample.-The 239 mothers were primarily literate (ac- cording to their self-report), married or in a union, urban-born, and relatively unschooled. Incomes were low, with the average family income per family member of 66 quetzales, which was equivalent at that time to about $\$ 35.00$.

Most (92\%) breastfed their children, and only $21 \%$ stopped before 3 months of age. The most common reason given for stopping breastfeeding was that the child was too old or too big $(16 \%)$; work was mentioned only by $7 \%$ of the mothers as a reason for stopping breastfeeding. Most also mixed breast- and bottle-feeding; $76 \%$ of the mothers had bottle-fed their children, with over half beginning during the child's first month of life.

Anthropometric status.-The sample was relatively undernourished, according to the NCHS standards. Using a standard risk threshold of $-2 \mathrm{SD}, 40 \%$ were below for height for age, $22 \%$ were below for weight for age, and $16 \%$ were below for weight for height.

Work patterns of mothers.-Forty-six percent of mothers reported working for income at some time during the past 12 months. Of the 112 workers, $62 \%$ were informal workers, and $35 \%$ were formal workers. Women tended to work relatively few hours per day but most days a week. The median number of days a week worked was 6 , the median hours per day was 5. Among the workers, $35 \%$ were occasional, $42 \%$ part time, and $23 \%$ full time.

Formal work was primarily either full time $(41 \%)$ or part time $(50 \%)$, whereas informal work tended to be either occasional $(51 \%)$ or part time $(37 \%)$, a significant interaction, $\chi^{2}(2, N=239)=24.67, p<.00$. Half of the workers worked through their ninth month of pregnancy, and $66 \%$ of the workers began to work again 2 months after the birth of their most recent child (33\% began at less than 2 months).

Socioeconomic characteristics of workers.-Table 1 shows means and standard deviations of socioeconomic and demographic variables by type of work and amount of work. One-way analyses of variance of mother's work type (none, informal, formal) and work amount (full, part, occasional, or none) were performed for mother's education, income per capita, house quality, marital status, child age, and birth order. Chi-square analyses were performed to compare the work variables with marital status.

Informal workers tended to be the poor- 
TABLE 1

Characteristics of Sample Families by Work Category

\begin{tabular}{|c|c|c|c|c|c|c|}
\hline \multirow[b]{3}{*}{ VARIABLE } & \multicolumn{6}{|c|}{ Work Category } \\
\hline & \multicolumn{2}{|c|}{$\begin{array}{c}\text { None } \\
(n=127)\end{array}$} & \multicolumn{2}{|c|}{$\begin{array}{l}\text { Informal } \\
(n=68)\end{array}$} & \multicolumn{2}{|c|}{$\begin{array}{c}\text { Formal } \\
(n=44)\end{array}$} \\
\hline & $M$ & $\mathrm{SD}$ & $M$ & $\mathrm{SD}$ & $M$ & SD \\
\hline 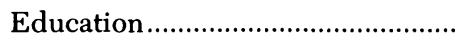 & 4.0 & 3.5 & 2.6 & 3.1 & 7.2 & 4.0 \\
\hline 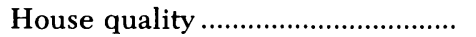 & 12.1 & 3.1 & 10.7 & 3.5 & 13.2 & 2.3 \\
\hline Income per capita ${ }^{a} \ldots \ldots \ldots \ldots \ldots \ldots \ldots \ldots$ & 50 & 52 & 61 & 67 & 96 & 88 \\
\hline Family income/month ${ }^{\mathrm{a}}$.................... & 220 & 134 & 299 & 315 & 417 & 344 \\
\hline Mother's income/month ${ }^{\mathrm{a}}$................ & 0 & 0 & 58 & 40 & 167 & 122 \\
\hline 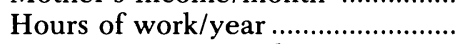 & 0 & 0 & 757 & 41 & 2079 & 1560 \\
\hline Percent income mother earns ........ & 0 & 0 & 32.4 & 30.1 & 43.3 & 29.0 \\
\hline 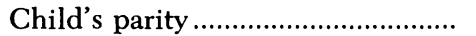 & 1.4 & 1.5 & 2.1 & 1.6 & 1.5 & 1.8 \\
\hline \multirow[t]{4}{*}{ Percent married .................................. } & 96 & & 85 & & 80 & \\
\hline & \multicolumn{6}{|c|}{ WORK AMOUNT } \\
\hline & \multicolumn{2}{|c|}{$\begin{array}{c}\text { Occasional } \\
(n=39)\end{array}$} & \multicolumn{2}{|c|}{$\begin{array}{c}\text { Part-Time } \\
(n=47)\end{array}$} & \multicolumn{2}{|c|}{$\begin{array}{c}\text { Full-Time } \\
(n=26)\end{array}$} \\
\hline & $M$ & $\mathrm{SD}$ & $M$ & SD & $M$ & $\mathrm{SD}$ \\
\hline 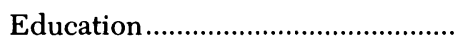 & 3.3 & 3.0 & 5.5 & 5.0 & 4.3 & 3.4 \\
\hline 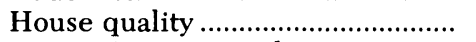 & 10.8 & 3.5 & 12.1 & 3.2 & 12.2 & 3.2 \\
\hline 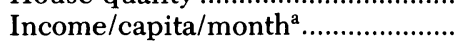 & 64 & 78 & 82 & 68 & 75 & 94 \\
\hline Family income/month ${ }^{\mathrm{a}}$..................... & 325 & 364 & 383 & 300 & 308 & 337 \\
\hline Mother's income/month ${ }^{\mathrm{a}} \ldots \ldots \ldots \ldots \ldots . . . . .$. & 43 & 27 & 129 & 110 & 130 & 107 \\
\hline 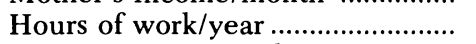 & 175 & 111 & 966 & 505 & 3490 & 1075 \\
\hline Percent income mother earns ....... & 23.8 & 25.0 & 37.2 & 25.3 & 55.3 & 35.1 \\
\hline Child's parity & 2.1 & 1.9 & 1.8 & 1.7 & 1.7 & 1.5 \\
\hline Percent married.................................. & 100 & & 81 & & 62 & \\
\hline
\end{tabular}

NoTE.-In the second part of the table, mothers are reclassified according to work amount; the same number of families have mothers who are "not working" in both parts of the table.

${ }^{a}$ All amounts expressed in quetzales, valued at approximately three to a dollar at the time of the interviews.

est and least educated of the three groups. Years of education differed significantly by work type, $F(2,237)=22.98, p<.0001$, with protected $t$ tests indicating that formal workers were more educated than nonworkers, who in turn were more educated than informal workers. Both per capita family incomes and house quality differed by work type, $F(2,237)=15.25, p<.01 ; F(2,237)=9.19$, $p<.01$; formal workers had better houses and their families earned more than informal workers' families. The index children of the informal workers were significantly laterborn than the formal or nonworkers' children, $F(2,237)=4.05, p<.05$, but there were no differences in age of the children. Informal and formal workers were more likely to be single ( $15 \%$ and $20 \%$, respectively) than nonworkers (4\%), $\chi^{2}(2, N=239)$ $=12.16, p<.001$.

Fewer variables differentiated the women by amount of work than work type. Significant $F$ values were seen for education, $F(3,236)=2.70, p<.05$, and family income per capita, $F(3,236)=3.21, p<.05$. Paired comparisons (protected $t$ tests) indicated significantly higher educational levels for the part-time workers than the occasional workers, but full-time workers did not differ from part-time and occasional workers on level of education. Part- and full-time workers had significantly higher family incomes per capita than nonworkers. Full-time workers were less likely to be married $(62 \%)$ than parttime $(81 \%)$, occasional $(100 \%)$, or nonworkers (96\%), $\chi^{2}(2, N=239)=37.16, p<.00$. No differences in house quality, the child's birth order, or age were found by work amount.

Mother's work and anthropometric status of children.-A one-way analysis of variance of work type on anthropometric indices 
without statistical controls found significant differences on height for age, $F(2,236)=$ $3.85, p<.02$, and weight for age, $F(2,236)$ $=4.18, p<.01$, but not weight for height. Protected $t$ tests indicated that children of informal workers were significantly lower than the other two groups. No differences in anthropometric indices by work amount were found.

One-way analyses of covariance of work type (none, informal, or formal) and work amount (none, occasional, part time, and full time) on anthropometric status adjusting for education of the mother, family income per family member, house quality, child's age in months, gender, marital status, and birth order were performed. Adjusted means and $F$ and $b$ values for anthropometric measures are shown in Table 2. For the work amount analyses, with four means, paired comparisons were made using protected $t$ tests with Bonferroni's correction; alpha levels of .01 were considered significant. When socioeconomic variables were controlled for, no significant effects were found for work type or work amount on any anthropometric indicator.

Child-care strategies.-Three major types of child care that working mothers used were leaving the child with another family member $(60 \%)$, working at home with the child $(21 \%)$, or taking the child to the workplace $(19 \%)$. For two children, there was insufficient information to code their child-care strategies. Of those leaving the child with another, 24 , or $25 \%$, paid that person. All but four reported being satisfied with the care their child was receiving.

The child-care abilities of the alternate caretaker were not assessed directly, but it was assumed that a relatively young child would not be as good a caretaker as a teenager or an adult. Therefore, child watchers were divided into those who were not yet teenagers (preteen siblings) and older child watchers (13-year-olds through grandmothers). Nineteen percent of working mothers relied on care by a preteen while they were out of the home, compared to $41 \%$ who relied on teens and adults. The youngest caregiver was 5 , but most of the preteen caregivers were between 10 and 12 . All were siblings or other family members of the target child.

Workers' child-care strategies varied by type of work, $\chi^{2}(3, N=110)=13.89, p<$ .003. Informal workers relied equally on all four strategies, but formal workers relied primarily on care by a teenager or adult $(60 \%)$. Workers' child-care strategies did not vary significantly with hours of work, although full-time workers rarely relied on care by a preteen (4\%) compared to part-time and occasional workers (about $23 \%$ each).

The child-care strategy used was unrelated to the socioeconomic and demographic

TABLE 2

F VAlues and Adjusted Means ${ }^{\text {a }}$ For ANTHropometric Status Z Scores by Type and AMOUnt OF MOTHER's Work

\begin{tabular}{|c|c|c|c|c|c|}
\hline \multirow[b]{2}{*}{ INDICATOR } & \multirow[b]{2}{*}{$F_{\text {model }}$} & \multirow[b]{2}{*}{$F_{\text {work }}$} & \multicolumn{3}{|c|}{ TYPE OF WORK } \\
\hline & & & None & Informal & Formal \\
\hline Height for age ............ & $5.29 * *$ & .12 & -1.75 & -1.79 & -1.66 \\
\hline Weight for age ............. & $4.82 * *$ & 1.00 & -1.27 & -1.39 & -1.08 \\
\hline \multirow[t]{3}{*}{ Weight for height....... } & 1.84 & 1.23 & -.23 & -.34 & -.05 \\
\hline & & & \multicolumn{3}{|c|}{ AMOUNT OF WORK } \\
\hline & & & Occasional & Part-Time & Full-Time \\
\hline Height for age ............. & $4.74^{* *}$ & .09 & -1.82 & -1.70 & -1.68 \\
\hline Weight for age .............. & $4.56^{* *}$ & 1.34 & -1.51 & -1.22 & -.96 \\
\hline Weight for height........ & $2.13^{*}$ & 2.31 & -.46 & -.21 & .14 \\
\hline
\end{tabular}

NoTE $-n=239$.

a Adjusted for child's age in months, mother's education, income per capita, house quality, birth order, marital status, and gender by General Linear Regression model (SAS Institute, 1985).

${ }^{\mathrm{b}}$ Nonworkers were also included in the regression; these means are shown in the top section of the table.

$* p<.05$.

${ }^{* *} p<.01$. 
variables, except family income per month, $F(4,233)=2.87, p<.05$. Paired comparisons suggested that families with adult caregivers had significantly higher incomes per capita than families with nonworking mothers.

Child-care strategies and children's anthropometric status. - A one-way analysis of variance of child-care method on the three anthropometric status indicators showed no differences for height for age and weight for age. Weight for height differed significantly by child care method, $F(4,232)=3.10, p<$ .02 . Means for each method of child care were compared with nonworkers' scores, resulting in four comparisons per anthropometric status indicator. Using Bonferroni's inequality (Miller, 1981), an alpha level of .01 was considered significant. Children cared for by a preteen were significantly lower in weight for height than those of nonworkers $(p<.008)$.

The same analysis was repeated controlling for mother's education, family income per capita, house quality, age of the child in months, birth order, marital status, and gender. Table 3 shows adjusted mean scores for the anthropometric indicators, and $F$ values for the model and for the variable of childcare method are shown.

As in the previous analysis, type of child care was significantly associated with weight for height, but not for the other two indicators, and children cared for by a preteen were significantly lower than children of nonworkers $(p<.01)$.

Combined work type and child-care effects.-Given the relatively small sample sizes of work type and child-care categories, and problems of multicolinearity, independent or interactive effects of child care and work type must be considered tentative. Using the same model as in the previous analysis, a 3 (work type) $\times 5$ (child-care type) analysis of covariance was performed using the General Linear Model with an interaction term of work type $\times$ child-care method. Since none of the interaction terms were significant, the analysis was repeated without the interaction term.

When both work type and child-care strategy were entered in the GLM, childcare strategy continued to be associated with weight for height, even controlling for work type, $F_{\text {model }}(12,223)=2.32, p<.01$; $F_{\text {care }}(3,223)=3.68, p<.01$. It appears that quality of child care is more important during these years of the child's life than maternal employment, controlling for SES.

Workers only: Maternal work and anthropometric status. - Characteristics of mother's income earning that might be associated with anthropometric status were her income per month, the percent of the family's income she earned, and the total number of hours she had worked in the previous year. Correlations of these variables with the three anthropometric measures are shown in Table 4. The woman's income per month was correlated with both height for age and weight for age, whereas the mother's percent of family income earned was related only to weight for age.

Because maternal work for earnings was associated with a number of the SES variables, and the SES variables were interrelated (e.g., families with more income had more educated mothers), the net associations of maternal earnings, hours of work, and percent of family income earned on children's anthropometric status were calcu-

TABLE 3

$F$ VALUES AND AdJUSTED MEANS ${ }^{\mathrm{a}}$ FOR NUTRITIONAL Status Z SCORES by ChILd-Care Method

\begin{tabular}{|c|c|c|c|c|c|c|c|}
\hline \multirow[b]{2}{*}{ INDICATOR } & \multirow[b]{2}{*}{$F_{\text {model }}$} & \multirow[b]{2}{*}{$F_{\text {care }}$} & \multicolumn{5}{|c|}{ Child-CaRe Method } \\
\hline & & & $\begin{array}{c}\text { None } \\
(n=127)\end{array}$ & $\begin{array}{c}\text { Works at } \\
\text { Home } \\
(n=23)\end{array}$ & $\begin{array}{c}\text { Mother } \\
\text { Takes Child } \\
(n=21)\end{array}$ & $\begin{array}{c}\text { Adult } \\
\text { Care } \\
(n=45)\end{array}$ & $\begin{array}{c}\text { Preteen } \\
\text { Care } \\
(n=21)\end{array}$ \\
\hline Height for age.......... & $4.31 * *$ & .28 & -1.75 & -1.93 & -1.55 & -1.72 & -1.71 \\
\hline Weight for age ......... & $4.28 * *$ & 1.55 & -1.27 & -1.51 & -.99 & -1.11 & -1.60 \\
\hline Weight for height ... & $2.29 * *$ & $2.85^{* *}$ & -.22 & -.34 & .02 & -.05 & -.72 \\
\hline
\end{tabular}

a Adjusted for child's age in months, mother's education, income per capita, house quality, birth order, marital status, and gender by General Linear Regression Model (SAS Institute, 1985).

$* p<.05$.

$* * p<.01$ 
TABLE 4

CORRELATIONS OF SOCIOECONOMIC VARIABLES AND WORK VARIABLES WITH ANTHROPOMETRIC INDICATORS

\begin{tabular}{|c|c|c|c|}
\hline \multirow[b]{2}{*}{ VARIABLE } & \multicolumn{3}{|c|}{ ANTHROPOMETRIC STATUS INDICATOR } \\
\hline & $\begin{array}{l}\text { Height for } \\
\text { Age }\end{array}$ & $\begin{array}{l}\text { Weight for } \\
\text { Age }\end{array}$ & $\begin{array}{c}\text { Weight for } \\
\text { Height }\end{array}$ \\
\hline \multicolumn{4}{|l|}{ All subjects $(n=239)$ : } \\
\hline Age in months .......................... & .05 & $.13^{*}$ & .08 \\
\hline 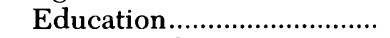 & $.34^{* *}$ & $.26 * *$ & .04 \\
\hline House quality ........................... & $.25^{* *}$ & $.17 * *$ & -.03 \\
\hline Income per capita ................. & $.21 * *$ & $.21^{* *}$ & .11 \\
\hline Birth order .............................. & $-.23^{* *}$ & $-.18^{* *}$ & -.07 \\
\hline \multicolumn{4}{|l|}{ Workers only $(n=112)$ : } \\
\hline Hours of work/year ............. & .01 & .07 & .12 \\
\hline Mother's income/month ... & $.26^{* *}$ & $.25^{* *}$ & .13 \\
\hline $\begin{array}{l}\text { Percent family income } \\
\text { mother earns .......................... }\end{array}$ & $.17^{\mathrm{a}}$ & $.20^{*}$ & .14 \\
\hline
\end{tabular}

$$
\begin{aligned}
& { }^{*} p<.05 \\
& { }^{* *} p<.01
\end{aligned}
$$

lated with a multiple linear regression in which all potentially confounding variables were entered together. Table 5 shows the slopes for the multiple regressions of these variables on anthropometric status for working mothers. Controlling for these variables, percent income earned by the mother was significantly associated with all three anthropometric measures, and neither mother's income nor hours per year were related to the child measures.
When many associated variables are included in a regression, the possibility that multicolinearity of variables may spuriously inflate some slopes is a concern. Multicolinearity was probably not a factor in these regressions, since none of the variables were correlated with each other above $r=.60$. However, to be sure, a stepwise multiple regression was computed allowing all three work variables plus SES variables to enter. Percent income earned by mother entered

TABLE 5

General Linear Regression MODEL of Work on ANTHRopometric INDicators

\begin{tabular}{|c|c|c|c|}
\hline \multirow[b]{2}{*}{ VARIABLE } & \multicolumn{3}{|c|}{ ANTHROPOMETRIC STATUS INDICATOR } \\
\hline & $\begin{array}{l}\text { Height for Age } \\
\qquad(b)\end{array}$ & $\begin{array}{l}\text { Weight for Age } \\
(b)\end{array}$ & $\begin{array}{l}\text { Weight for Height } \\
\qquad(b)\end{array}$ \\
\hline Age in months........................ & .010 & $.036^{* *}$ & $.031^{* *}$ \\
\hline 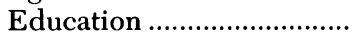 & $.074^{*}$ & .046 & -.001 \\
\hline House quality........................ & .065 & .045 & .001 \\
\hline Income per capita ............... & .003 & .004 & .003 \\
\hline 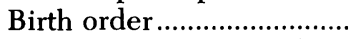 & -.036 & .017 & .042 \\
\hline Gender $(1=m, 2=f) \ldots$ & -.277 & -.360 & -.255 \\
\hline Marital status $(0=$ no $) \ldots .$. & $.919 *$ & $1.060^{* *}$ & $.666^{*}$ \\
\hline Hours of work/year............. & -.000 & -.000 & .000 \\
\hline Mother's income/month... & -.000 & -.002 & -.001 \\
\hline $\begin{array}{l}\text { Percent family income } \\
\text { mother earns ................... }\end{array}$ & $.019 * *$ & $.021^{* *}$ & $.010^{*}$ \\
\hline 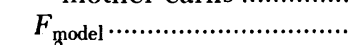 & $3.47^{* *}$ & $3.95^{* *}$ & $2.04^{*}$ \\
\hline 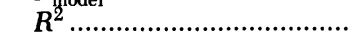 & .27 & .29 & .18 \\
\hline
\end{tabular}
FOR CHILDREN OF WORKING MOTHERS ONLY: $b$ VALUES

Note. $-n=107$ because income could not be calculated for five subjects.

$* p<.05$.

${ }^{* *} p<.01$. 
second after mother's education, whereas hours of work per year and the woman's income per month did not enter. It appears that the percent of income earned by the mother may be more important for children's weight and height than amount of her income during this developmental period of the child's life.

Age comparisons.-These analyses were performed with the subjects over 35 months $(N=108)$, both index children and siblings over 35 months. There were no significant effects of maternal work variables on any anthropometric indicator, or for percent of income earned by the mother (workers only).

\section{Discussion}

The hypothesis that 8-35-month-old children of formal workers would have higher anthropometric status than children of nonworkers was not supported; children of formal workers were equally well, but not better, nourished than those of nonworkers. Children of informal workers were significantly lower in anthropometric indicators than children in the other two groups. However, informal work was highly associated with socioeconomic variables that endanger the child's possibilities of achieving adequate growth (education and income). When these variables were statistically controlled, no effects of work type were seen. The lack of difference in the anthropometric status of children when SES factors are controlled for might argue for a positive effect of work for these children, since had the mother not worked, the children might have faced much more hardship. The data illustrate the difficult circumstances the informal workers face, their relative poverty, and the little income they receive for their work.

It had been predicted that the amount of time worked should be less highly associated with children's growth status than type of work (probably a proxy for wage rate). This hypothesis was supported; although mothers who worked more hours tended to be somewhat wealthier and better educated than those who worked less, no associations of amount of work with anthropometric status were seen. When socioeconomic variables were controlled, full-time workers had children with slightly higher weight for height than nonworkers.

Among the group of workers, the percent of the family's income that the mother earned was significantly associated with all three anthropometric indicators, whereas income from her earnings and her hours of work were unrelated to anthropometric indicators, controlling for socioeconomic and demographic variables.

Other studies have shown positive effects of maternal work for earnings on children's anthropometric status, controlling for SES variables during this age period (Haggerty, 1981; Kumar, 1977). In the 1975 data from the same villages (Engle \& Pedersen, 1989), 2-year-old children of formal workers had been better nourished than children of nonworkers, controlling for maternal education and income. In the earlier study, the positive effects of work during the second year of life were related to differential spending patterns of women with income; specifically, the working mothers of 2-yearolds were more likely to purchase highcaloric-density weaning foods than the nonworking mothers of 2-year-olds. There is a growing body of literature suggesting that a mother's income is more likely to be used to supply basic needs of children than a father's income (Blumberg, 1988; Dwyer \& Bruce, 1988; Engle, in press). In this study, the percent of the family's income that was earned by the mother was highly related to the child's anthropometric status. Percent income earned may be associated with control of income, or decision-making power (Engle, 1990). Perhaps this decision-making role, rather than type of work, is the dimension of maternal work for earnings that is associated with children's nutritional status.

It had been suggested that the effects of maternal work for earnings on children's anthropometric status would be greater in the 8-35-month period than during the 3648-month period. As expected, there were no effects of maternal work for earnings in the latter group. These results cannot be considered conclusive, since the older group is not strictly comparable, but the lack of effect is similar to results from other studies (Engle \& Pedersen, 1989; Tucker, 1989: Wilson, 1981). The latter two studies found no difference in nutritional status by work status of the mother, even though children of working mothers had higher dietary intakes.

The hypothesis that no negative effects of maternal work would be seen if the caregiving environment were positive (care by an adult or care by mother when she is working in the home) seemed to be supported. There was no evidence that children taken care of by adults, by mothers who took chil- 
dren with them, or mothers who watched the children in the home were any more undernourished than children whose mothers did not work. However, children cared for by a preteen sibling had lower weight for height, even when socioeconomic, demographic, and work type variables were controlled for. Concern should be raised about mothers who need to rely on preteen care, both for the young children and for their caregivers.

\section{References}

Berkey, C. S., \& Reed, R. B. (1987). A model for describing normal and abnormal growth in early childhood. Human Biology, 59, 973-987.

Bittencourt, S., \& DiCicco, E. (1979). Child care needs of low income women: Urban Brazil (Report to USAID). Washington, DC: Overseas Education Fund.

$\rightarrow$ Blumberg, R. L. (1988). Income under female versus male control. Journal of Family Issues, 9 , 51-84.

Cassidy, C. M. (1980). Benign neglect and toddler malnutrition. In F. E. Johnston \& L. S. Greene (Eds.), Social and biological predictors of nutritional status, physical growth, and neurological development (pp. 109-136). New York: Academic Press.

Dwyer, D. H., \& Bruce, J. (1988). A home divided. Stanford, CA: Stanford University Press.

Engle, P. L. (1983). Maternal employment and child mortality in rural Guatemala. In D. Wagner (Ed.), New Directions in child development: Vol. 20. Child development and international development: Research-policy interfaces (pp. 57-75). San Francisco: Jossey-Bass.

Engle, P. L. (1989a). Child care strategies of working and nonworking mothers in rural and urban Guatemala. In J. Leslie \& M. Paolisso (Eds.), Women, work, and child welfare in the third world (pp. 179-200). Boulder, CO: Westview.

Engle, P. L. (1989b, April). The social context of maternal employment in Guatemala: Is there a child care crisis? Paper presented at biennial meeting of the Society for Research in Child Development, Kansas City, MO.

Engle, P. L. (1990). Intra-household allocation of resources: Perspectives from psychology. In B. L. Rogers \& N. P. Schlossman (Eds.), Intra-household resource allocation (pp. 63-78). Tokyo: United Nations University Press.

Engle, P. L. (in press). Influences of mother's and father's income on children's nutritional status in Guatemala. Social Science and Medicine.
Engle, P. L., Irwin, M., Klein, R. E., Yarbrough, C., \& Townsend, J. (1979). Nutrition and mental development in children. In M. Winick (Ed.), Nutrition: Pre- and postnatal influences (pp. 75-92). New York: Plenum.

Engle, P. L., \& Pedersen, M. E. (1989). Maternal work for earnings and children's nutritional status in urban Guatemala. Ecology of Food and Nutrition, 22, 211-223.

Gibbons, G., \& Griffiths, M. (1984). Program activities for improving weaning practices (Report prepared for UNICEF). Washington, DC: American Public Health Association.

Gordon, J. E., Wyon, J. B., \& Ascoli, W. (1967). The second year death rate in less developed countries. American Journal of Medical Sciences, 254, 357-380.

Grant, J. P. (1989). The state of the world's children: 1989. New York: Oxford University Press.

Haggerty, P. (1981). Women's work and child nutrition in Haiti. Unpublished master's thesis, M.I.T., Cambridge, MA.

Herrera, M. G. (1987). Maternal nutrition and child survival. In R. Cash, G. T. Keusch, \& J. Lamstein (Eds.), Child health and survival: The UNICEF GOBI-FFF program (pp. 75-98). Kent: Croom Helm.

Joekes, S. (1989). Women's work and social support for child care in the third world. In J. Leslie \& M. Paolisso (Eds.), Women, work, and child welfare in the third world ( $\mathrm{pp}$. 59-84). Boulder, CO: Westview.

Johnston, F. E., Low, S. M., De Baessa, Y., \& MacVean, R. B. (1987). Interaction of nutritional and socioeconomic status as determinants of cognitive development in disadvantaged urban Guatemalan children. American Journal of Physical Anthropology, 51, 501-506.

Johnston, F. E., Newman, B., Cravioto, J., DeLicardie, E., \& Scholl, T. (1980). A factor analysis of correlates of nutritional status in Mexican children, birth to 3 years. In L. S. Greene \& F. E. Johnston (Eds.), Social and biological predictors of nutritional status, physical growth, and neurological development (pp. 291-307). New York: Academic Press.

Joos, S. K., Pollitt, E., Mueller, W. H., \& Albright, D. (1983). The Bacon Chow study: Maternal nutritional supplementation and infant behavioral development. Child Development, 54, 669-676.

Jordan, M., \& Staehling, N. (1986). Anthropometric statistical package, version 3 [statistical program]. Atlanta: Centers for Disease Control.

Kumar, S. H. (1977). Role of the household economy in child nutrition at low incomes: A case study in Kerala (Occasional Paper No. 95). 
Ithaca, NY: Cornell University, Department of Agricultural Economics.

Leslie, J. (1988). Women's work and child nutrition in the third world. World Development, 16, 1341-1362.

Leslie, J. (1989). Women's work and child nutrition in the third world. In J. Leslie \& M. Paolisso (Eds.), Women, work, and child welfare in the third world (pp. 19-58). Boulder, CO: Westview.

Leslie, J., \& Paolisso, M. (1989). Women, work, and child welfare in the third world. Boulder, CO: Westview.

Martorell, R., \& Klein, R. E. (1980). Food supplementation and growth rates in preschool chil dren. Nutrition Reports International, 21, 447-454.

Martorell, R., Klein, R. E., \& Delgado, H. (1980). Improved nutrition and its effects on indicators of nutritional status. Nutrition Reports International, 21, 219-230.

Miller, R. G., Jr. (1981). Simultaneous statistical inference. New York: Springer-Verlag.

Mueller, W. H., \& Pollitt, E. (1983). The Bacon Chow study: Genetic analysis of physical growth in assessment of energy-protein malnutrition. American Journal of Physical Anthropology, 62, 11-17.

O'Gara, C. (1989). Breastfeeding and maternal employment in urban Honduras. In J. Leslie \& M. Paolisso (Eds.), Women, work and child welfare in the third world (pp. 113-130). Boulder, CO: Westview.

Pollitt, E., Gorman, K., \& Metallinos-Katsaras, E. (1989, October). Infant anthropometry as a developmental predictor. Paper presented at the Cornell Symposium on Human Development, Ithaca, NY.

$\rightarrow$ Pollitt, E., Mueller, W., \& Leibel, R. L. (1982). Relation of growth to cognition in a wellnourished preschool population. Child Development, 53, 1157-1163.

Popkin, B., \& Lim-Ybanez, M. (1982). Nutrition and school achievement. Social Science and Medicine, 16, 53-61.

SAS Institute (1985). Statistical analysis system [computer program]. Cary, NC: SAS Institute.

Shah, P. M., Walimbe, S. R., \& Dhole, V. S. (1979). Wage-earning mothers, mother-substitutes, and care of the young child in rural Maharashtra. Indian Pediatrics, 16, 167-173.

Sigman, M., Neumann, C., Carter, E., Cattle, D. J., D’Souza, S., \& Bwibo, N. (1988). Home interactions and the development of Embu toddlers in Kenya. Child Development, 59, 1251-1261.

$\rightarrow$ Sigman, M., Neumann, C., Jansen, A. A. J.,
\& Bwibo, N. (1989). Cognitive abilities of Kenyan children in relation to nutrition, family characteristics and education. Child Development, 60, 1463-1474.

Soekirman. (1985, July). Women's work and its effects on infants' nutritional status in central Java, Indonesia. Paper presented at the 13th International Congress of Nutrition, Brighton, England.

Super, C. M., \& Harkness, S. (1986). The developmental niche: A conceptualization at the interface of child and culture. International Journal of Behavioral Development, 9, 545-569.

Super, C. M., Herrera, M. G., \& Mora, J. O. (1990). Long-term effects of food supplementation and psychological intervention on the physical growth of Colombian infants at risk of malnutrition. Child Development, 61, 29-49.

Townsend, J. W., Klein, R. E., Irwin, M. C., Owens, W., Yarbrough, C., \& Engle, P. L. (1982). Nutrition and preschool mental development. In D. A. Wagner \& H. W. Stevenson (Eds.), Cultural perspectives on child development (pp. 124-145). San Francisco: W. H. Freeman.

Tripp, R. B. (1981). Farmers and traders: Some economic determinants of nutritional status in Northern Ghana. Journal of Tropical Pediatrics, 27, 15-22.

Tucker, K. (1989). Maternal employment, differentiation, and child health and nutrition in Panama. In J. Leslie \& M. Paolisso (Eds.), Women, work, and child welfare in the third world (pp. 161-178). Boulder, CO: Westview.

Werner, E. E. (1988). A cross-cultural perspective on infancy: Research and social issues. Journal of Cross-Cultural Psychology, 19, 96-113.

Wilson, A. B. (1981). Longitudinal analysis of diet, physical growth, verbal development, and school performance. In J. B. Balderston (Ed.), Malnourished children of the rural poor (pp. 39-82). Boston: Auburn House.

Wolfe, B. L., \& Behrman, J. (1982). Determinants of child mortality, health, and nutrition in a developing country. Journal of Developmental Economics, 11, 163-194.

World Health Organization (1983). Measuring change in nutritional status. Geneva: World Health Organization.

Zeitlin, M., Houser, R., \& Johnson, F. C. (1989, April). Active maternal feeding and nutritional status of 8-20-month-old Mexican children. Paper presented at the biennial meeting of the Society for Research in Child Development, Kansas City, MO. 